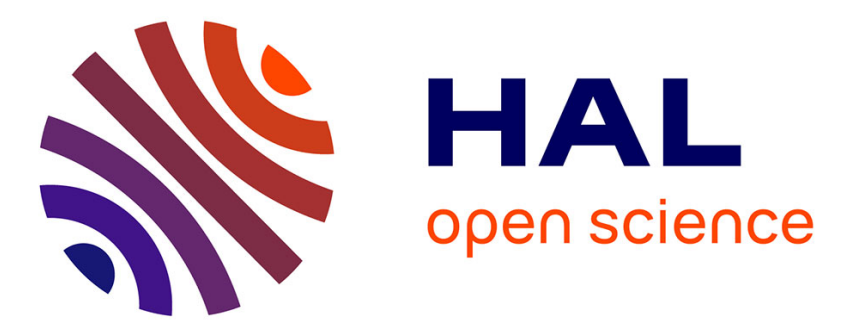

\title{
Juvenile Oblada melanura (L. 1758) otolith shape variation as an early environmental indicator
}

P.S.P. Vandenbussche, G. Spennato, P.M. Pierson

\section{To cite this version:}

P.S.P. Vandenbussche, G. Spennato, P.M. Pierson. Juvenile Oblada melanura (L. 1758) otolith shape variation as an early environmental indicator. Ecological Indicators, 2019, 104, pp.289 - 295. 10.1016/j.ecolind.2019.05.011 . hal-03485883

\section{HAL Id: hal-03485883 \\ https://hal.science/hal-03485883}

Submitted on 20 Dec 2021

HAL is a multi-disciplinary open access archive for the deposit and dissemination of scientific research documents, whether they are published or not. The documents may come from teaching and research institutions in France or abroad, or from public or private research centers.
L'archive ouverte pluridisciplinaire HAL, est destinée au dépôt et à la diffusion de documents scientifiques de niveau recherche, publiés ou non, émanant des établissements d'enseignement et de recherche français ou étrangers, des laboratoires publics ou privés.

\section{다)(1) $(5$}

Distributed under a Creative Commons Attribution - NonCommerciall 4.0 International 
Version of Record: https:/www.sciencedirect.com/science/article/pii/S1470160X19303450

Manuscript_75ad843784d6c32dc1f349c27502a817

$1 \quad$ Title: Juvenile Oblada melanura (L. 1758) otolith shape variation as an early environmental indicator

2 Author names: P.S.P. Vandenbussche, G. Spennato, P.M. Pierson

3 Affiliation: Université Nice Sophia Antipolis, UCA, CNRS, FRE 3729 ECOMERS, Faculté des Sciences, Parc

4 Valrose, 28 Avenue Valrose, 06108 Nice Cedex 2, France

5 Emails: vandenbussch@unice.fr, spennato@unice.fr, pierson@unice.fr

6 Corresponding author: P.S.P. Vandenbussche

7 Short title: Otolith shape variation as an environmental indicator

8 
Coasts are increasingly subject to the pressure of human activities, thus bioindicators of stress are also becoming necessary. We tested whether the otolith shape of Oblada melanura juveniles could be used as indicator of anthropic impacts. Otolith shapes, defined by Fourier elliptic analysis, were compared using canonical analysis of principal coordinates. In this three-year study, we compared two geographically close sites: one with low-level pollution and one near a recreational harbour. Determining the minimum fish standard length at which the influence of fish size on otolith shape does not occult other influences, $11 \mathrm{~mm}$ in this study, is a prerequisite for the study of otolith shape variation in juveniles. Inter-annual environmental variations interfere with local conditions and delays between samplings are also important considerations. We have demonstrated that the comparison of $O$. melanura juvenile otolith shape is an effective method to compare the short-term influence of different environmental conditions.

\section{Keywords:}




\section{Introduction}

Coasts consist of a variety of ecosystems (Ducrotoy and Yanagi, 2008), providing numerous services such as fish nursery sites (Cheminée et al., 2013; Cuadros et al., 2017) and habitats (Thiriet et al., 2016). They are degraded by human influences, such as residential development (Thia-eng and Ross, 1998), industry (Hildering et al., 2009), commerce, tourism (Petrosillo et al., 2009) and impacted by contamination events (Mestres et al., 2010). The monitoring of the anthropic impact on this environment is therefore necessary. The coastal area we have chosen to analyse is the French Riviera which is known to be affected by yachting activities.

Classical microbiological or chemical methods allow to measure known occasional pollution discharges. Complementary biological indicators that integrate environmental fluctuations over for a prolonged period are of great interest, for example using fishes (Cresson et al., 2015).

In fishes, otoliths can be considered as the hard disks that store the history of an individual (Secor et al., 1995). Otoliths are calcified structures of the inner-ear semi-circular system (Degens et al., 1969), which have a species specific shape (L'Abée-Lund, 1988; Morrow, 1979). They play a major role in audition and spatial recognition (Morales-Nin, 2000). They are composed of a keratin-like protein and calcium carbonate (Degens et al., 1969; Morales-Nin, 2000), and grow according to a circadian rhythm (MoralesNin, 2000; Panella, 1971). Their growth and shape are altered by environmental conditions (Anken et al., 1998; Campana and Casselman, 1993; Galley et al., 2006; Secor and Dean, 1989; Smith et al., 2002), making the otolith a potentially interesting tool for environmental surveys.

In order to use the otolith as an indicator, specific characteristics are required in the selection of the species: fishes must be sedentary in order to integrate local environment characteristics, and must rapidly integrate this information, which is the case for young fishes (Anken et al., 1998). In the North occidental Mediterranean, Oblada melanura (Linnaeus, 1758) are sedentary during the first two months 
of their life as juveniles (authors' observation). Therefore, we have chosen 0 . melanura juveniles for the present study.

The environment is known to influence otolith shape in adult fishes (Bose et al., 2018; Campana and Casselman, 1993; Galley et al., 2006; Rodgveller et al., 2017; Secor and Dean, 1989; Smith et al., 2002). In the case of $O$. melanura, living zone of an adult is superior to the one of a juvenile which is limited to a group of rocks and its immediate surroundings (authors' observation). Hence, to study the effect of local environment (maximum 100 m of linear coast) the adults are not adapted, we have chosen to study juveniles. The aim of the present study is to determine whether the otolith shape of juvenile Oblada melanura may also be used as an environmental indicator. For that purpose, several questions had to be addressed. As otolith shape changes with fish growth (Bose et al., 2018; Campana and Casselman, 1993; Secor and Dean, 1989), what is the size limit above which the otolith tends to stabilise into its adult shape i.e. sets aside the growth influence on otolith shape? Once this limit is determined, if a shape difference is observed, which parameters should be taken into account in order to properly interpret this result? Finally, is it possible to distinguish fishes from two nearby sites, as distance induces shape differences (Bacha et al., 2016, 2014; Campana and Casselman, 1993; Javor et al., 2011; Smith et al., 2002; Tracey et al., 2006), with different environmental conditions i.e. low-level pollution versus recreational harbour?

\section{Materials and methods}

Our samplings took place during the summers of 2013, 2014 and 2015, and two sites were sampled on the French coast of the North occidental Mediterranean Sea. These sites are geographically close (2.3 $\mathrm{km}$ apart) but present different environmental conditions. The first site, referred to as A $\left(43^{\circ} 43^{\prime \prime} 21.00^{\prime}\right.$ $\left.\mathrm{N} ; 7^{\circ} 21^{\prime \prime} 37.00^{\prime} \mathrm{E}\right)$, was selected, on the basis of the marine currents, in order to ensure that the level of anthropic pollution would be at a minimum. The second site, referred to as B $\left(43^{\circ} 42^{\prime \prime} 40.79^{\prime} \mathrm{N}\right.$; 
$\left.7^{\circ} 20^{\prime \prime} 14.89^{\prime} \mathrm{E}\right)$, was near an intermediate-sized recreational harbour, because harbours are known to be

71 sources of chemical contaminations (Damiens et al., 2007; Konstantinou and Albanis, 2004; McCoy and Johnson, 2010; Mestres et al., 2010; Telli Karakoc et al., 1997). The collected samples are presented in Table 1.

Table 1: Samples collected in 2013, 2014 and 2015.

\begin{tabular}{|c|c|c|c|c|c|c|c|c|c|c|}
\hline \multirow{2}{*}{$\begin{array}{l}\text { Site } \\
\text { Sampling }\end{array}$} & \multicolumn{6}{|l|}{ A } & \multicolumn{4}{|l|}{ B } \\
\hline & 1 & & 2 & & 3 & & 1 & & 2 & \\
\hline Year & Date & $\mathbf{N}$ & Date & $\mathbf{N}$ & Date & $\mathbf{N}$ & Date & $\mathbf{N}$ & Date & $\mathbf{N}$ \\
\hline 2013 & $07 / 10$ & 46 & $07 / 24$ & 51 & $07 / 30$ & 35 & & & & \\
\hline 2014 & $06 / 23$ & 81 & 07/03 & 61 & & & $06 / 23$ & 55 & 07/03 & 64 \\
\hline 2015 & $06 / 25$ & 74 & $06 / 30$ & 34 & & & $06 / 25$ & 62 & $06 / 30$ & 34 \\
\hline
\end{tabular}

75 Date: sampling date; $\mathrm{N}$ : number of fishes in each group.

76 For each year, fishes were sampled after at least a one-week stay at the site. In 2013 , only site A was 77 sampled for the preliminary stage of the study. A total of 597 fishes were analysed for otolith shape.

Two landing nets were used to catch the fishes which were immediately euthanatized by an overdose of an anaesthetic drug (Neiffer and Stamper, 2009). This method consisted of a minimum of 10 minutes immersion in a 2,038 g..$^{-1}$ clove oil seawater solution which is 50 times the anaesthetic dose for sparid fishes such as Sparus aurata and Dentex dentex (García-Gómez et al., 2002; Ross and Ross, 2008). Fishes were then frozen, placed in a Petri dish without water at $-20^{\circ} \mathrm{C}$ for preservation until extraction of the otoliths.

For each fish, standard length was measured to the nearest 1/10 millimetre $(\mathrm{mm})$ and otoliths (sagittae) were dissected using the "through the gill" method (Secor et al., 1992; VanderKooy and Guindon-Tisdel, 2003). Otoliths were carefully cleaned and placed on a glass microscope slide, with the sulcus facing the slide and the rostrum pointing upward (Bacha et al., 2014; Gonzalez-Salas and Lenfant, 2007; Jemaa et al., 2015; Stransky et al., 2008), and dried. For observation and photographs, we used a Zeiss AxioScope A1 microscope equipped with a 10x magnifier lens, coupled with a Canon EOS 550D camera. Each picture was saved in 8 bits grey scale 5184 x 3456 pixels, 300 dpi resolution. 
91 The whole outline of each right sagitta was then extracted using SHAPE ChainCoder (Iwata and Ukai,

92 2002) and saved as a chain code (Freeman, 1974). The resulting chain codes were then used for an

93 elliptic Fourier analysis (Giardina and Kuhl, 1977; Kuhl and Giardina, 1982) using Vincent Bonhomme's R

94 package "Momocs" (Bonhomme et al., 2014). 12 harmonics were used in order to describe 99\% of the

95 shape variation (Campana and Casselman, 1993). Each harmonic is defined by four constants (a, b, c and

96 d), thus each otolith shape is described by 48 variables. Because of otolith shape standardisation (size

97 and orientation), the values $a, b$ and $c$ of the first harmonic are specified constants $\left(a_{1}=1, b_{1}=0, c_{1}=0\right)$.

98 Consequently, this first harmonic is not used for further analyses.

99 The comparisons of fish groups were conducted using principal component analysis (PCA), analysis of 100 variance (ANOVA) and Tukey honest significant difference (HSD) as post-hoc test, or canonical analysis 101 of principal coordinates (CAP). Unconstrained ordination, such as PCA, computes the axes that best 102 describe the point dispersion of a multivariate dataset. Constrained ordination, such as CAP, computes 103 the axes that best separate a priori groups (Anderson et al., 2008; Anderson and Willis, 2003). CAP is a 104 constrained ordination with groups known a priori for which the computed cross-validation by the 105 success of allocation to the leave one out test gives a reasonable and nearly unbiased measurement of 106 how groups are distinct (Anderson et al., 2008; Anderson and Willis, 2003; Tracey et al., 2006). CAP was 107 performed after removing the first harmonic, because of standardisation, on between individuals 108 Euclidian distance, with 9999 unrestricted random permutations of the raw data (Anderson, 2001). PCA, 109 ANOVA and HSD were performed using R (V 3.3.0), CAP was computed using PRIMER 6.

\section{$1103 \underline{\text { Results }}$}

\section{$111 \quad 3.1 \quad$ Parameters to take into account}

$112 \quad$ 3.1.1 Determination of the limit for fish standard length 


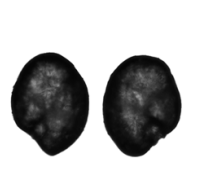

$7 \mathrm{~mm}$

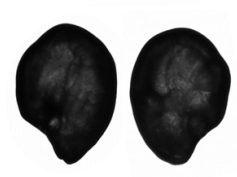

$8 \mathrm{~mm}$

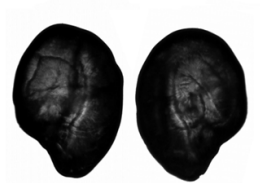

$9 \mathrm{~mm}$

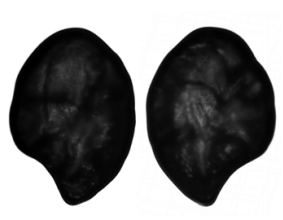

$10 \mathrm{~mm}$

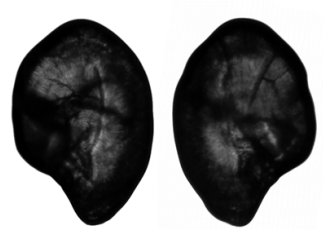

$11 \mathrm{~mm}$

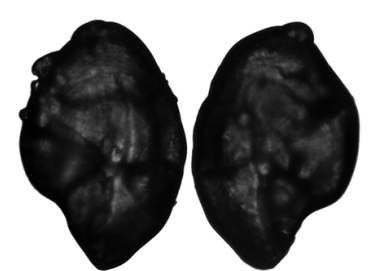

$12 \mathrm{~mm}$

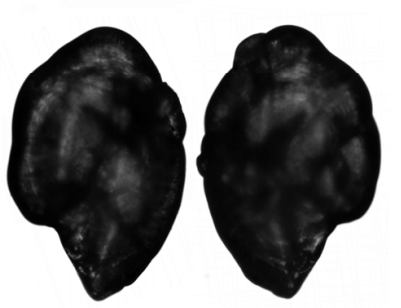

$13 \mathrm{~mm}$

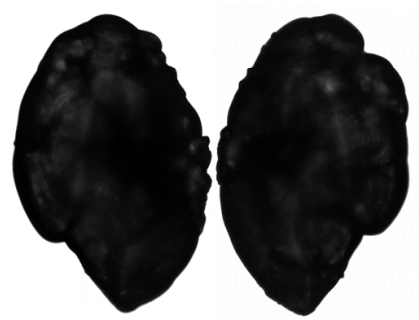

$14 \mathrm{~mm}$

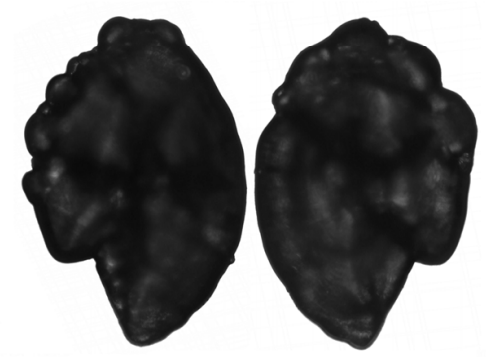

$15 \mathrm{~mm}$

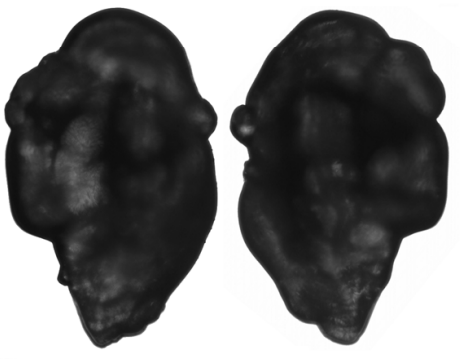

$16 \mathrm{~mm}$

Figure 1: Representative photographs of paired sagittae from Oblada melanura according to fish standard lengths ( $\mathrm{mm}$ ).

These sagittae photographs illustrate the shape complexification associated with increases in otolith and fish sizes during the first weeks of settlement.

As shown in Figure 1, as a fish grows the otolith shape changes from a "rounded" smooth shape to a "ovoid" jagged shape. year, is presented in Figure 2. 


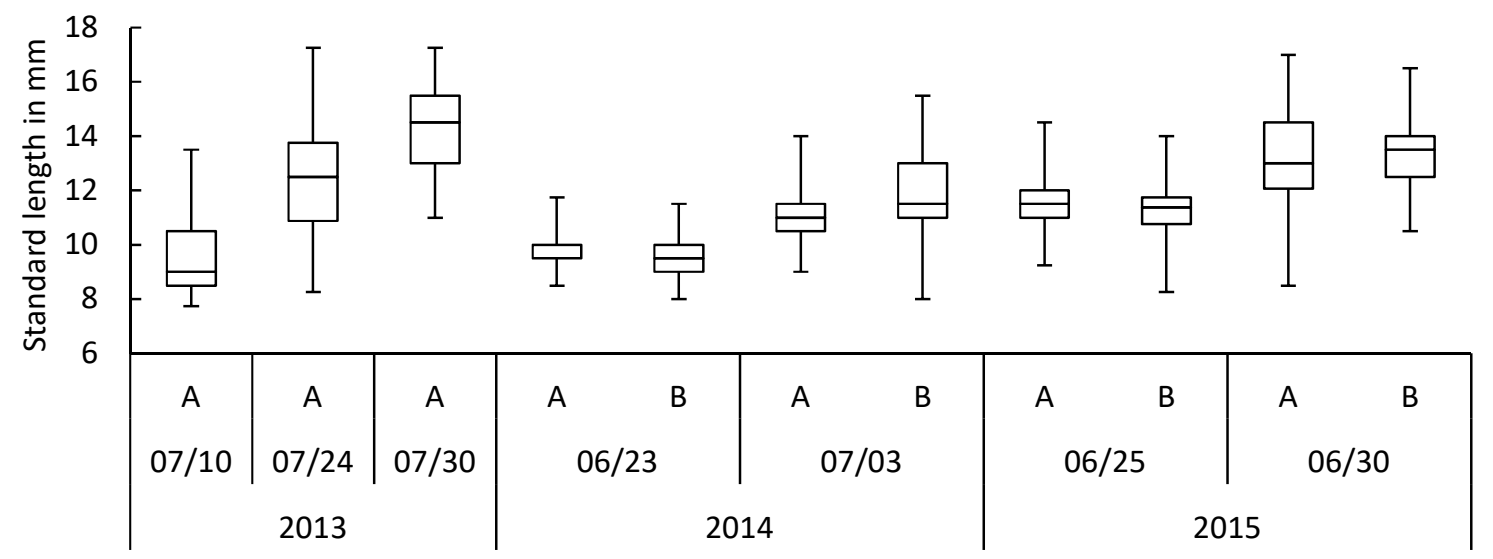

Figure 2: Fish standard length distribution according to sampling site types, sampling dates and years.

\section{A: low anthropic pollution level; B: intermediate-sized recreational harbour.}

Figure 2 suggests differences in standard length, at least between years and sampling dates. An ANOVA reveals significant differences $\left(F_{2,594}=54.15, p<10^{-4}\right)$ between sampling years, between each sampling date $\left(p<10^{-4}\right)$ and between types of environment for the second sampling in $2014\left(F_{1,123}=6.336, p=\right.$ 0.013). More interestingly, all standard lengths vary between 7.75 and $17.25 \mathrm{~mm}$, and the standardlength difference within each sample is between 3.25 and $9 \mathrm{~mm}$. Consequently, according to Figure 1, we expect strong otolith shape differences within the same sample.

This confirms the requirement for a defined size limit, in order to compare otolith shapes between sites and dates. In order to determine such a limit for these comparisons, we computed a PCA on the measured shape variables, including all the fishes (597 total) from the 2013, 2014 and 2015 samplings. In this PCA, $55.15 \%$ of the total variation is explained by the first principal component (PC1), then each lower order PC represents less than 10\%. The projection of the individuals among PC1 and PC2 (which together represent $63.73 \%$ of the total variation), with the superimposition of information from standard length groups constituted with a step size of $0.5 \mathrm{~mm}$ (from $<8.5$ to $17-17.5 \mathrm{~mm}$ ), is presented in Figure 3. 


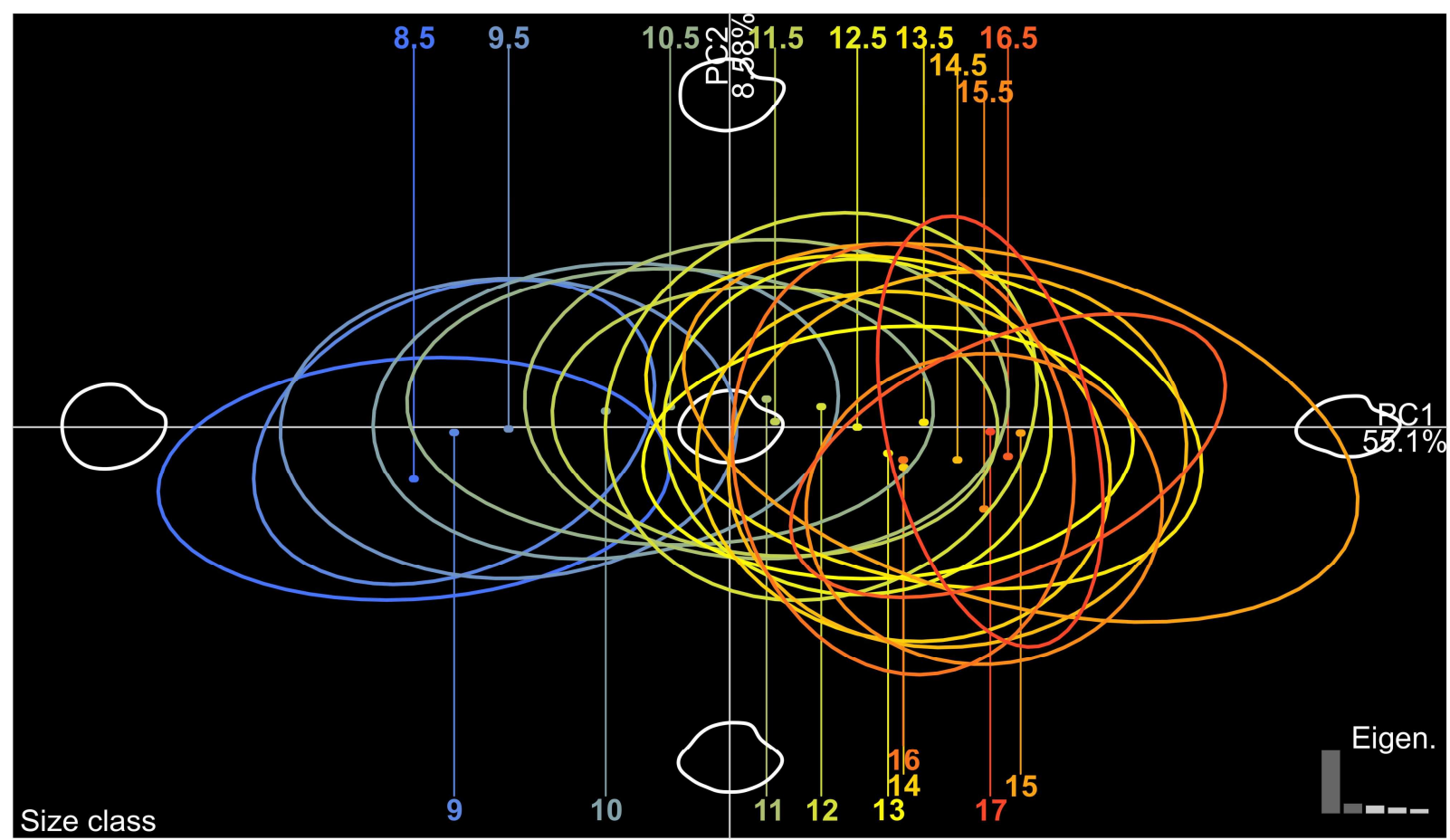

Figure 3: PCA of 597 O. melanura sampled in 2013, 2014 and 2015, grouped by standard lengths (mm).

PCA conducted on Fourier coefficients of the first 12 harmonics. Projection of the individuals across PC1 and PC2 axes. Ellipses: 95\% confidence clouds around group centroids; colours correspond to size classes; otolith shapes: shape evolution across PC axes. Size classes of $0.5 \mathrm{~mm}$ from < 8.5 (8.5) to 17-17.5 (17.5). Note that the 17.5 group, composed of only 2 fishes, is not presented. The first axis of this PCA effectively separates the otolith shapes according to their complexity. This shape complexity depends on fish size, with simple "rounded" shapes for the smallest sizes and complex "ovoid" shapes for the biggest sizes. The separation between size groups seems more pronounced for size classes up to 11 millimetres than for other classes.

It appears that size groups are well separated along the PC1 axis, with the smallest fishes being associated with negative values (corresponding to a "rounded" shape), and largest fishes with positive values (associated with a "ovoid" shape). The link between PC1 and fish standard length is confirmed by a strong correlation $\left(r_{\text {pearson }}=0.775, p<10^{-4}\right)$. According to Figure 3 , under the $11 \mathrm{~mm}$ standard length limit, the group centroids are clearly separated which indicates that otolith shape modification is associated with an increase in fish standard length. In contrast, over this $11 \mathrm{~mm}$ limit the group centroids tend to be superimposed, which indicates otolith shape stabilisation.

A comparison of the size groups using an ANOVA on PC1 reveals a highly significant difference between groups $\left(F_{18,578}=66.54 ; p<2.00 E-16\right)$. The Tukey HSD post-hoc test result indicates that, for standard length $>12 \mathrm{~mm}$, there is no difference between groups, with one exception (]12;12.5] vs. ]14.5;15], p=0.014), 
161 and that the differences are weaker for standard lengths of ]10.5; 11], ]11;11.5] and ]11.5;12] than for 162 lower standard lengths (see supplementary data). In view of this latter observation, we chose to focus 163 on fishes with a standard length $\geq 11 \mathrm{~mm}$, which seems to be the extreme limit. Note that, even with 164 this extended group, only 6 fishes were available for the 2014-06-23 sample (2 of type $A$ and 4 of type 165 B), so results for this date should be considered with caution.

166 Having determined the $11 \mathrm{~mm}$ size limit for standard length, we performed otolith shape comparisons.

167 For all the following analyses, we chose a constrained ordination, using CAP, in order to compare groups 168 according to otolith shapes, as this method was shown to be one of the best suited for this kind of data

169 (Tracey et al., 2006). As we had three variable parameters for our samplings (sampling years, dates and 170 site types), we independently tested a potential effect of each of these parameters on otolith shape 171 variation. Years and dates of sampling were tested as potential supplementary parameters to consider 172 before studying the effect of different environmental conditions on fishes.

\section{$173 \quad 3.1 .2$ Influence of the year of sampling}

174 Because environmental conditions may not be strictly the same between years, we compared the 175 otolith shape of samples from 2013, 2014 and 2015. A representation of the mean otolith shape 176 according to sampling dates reveals the differences (Figure 4). 


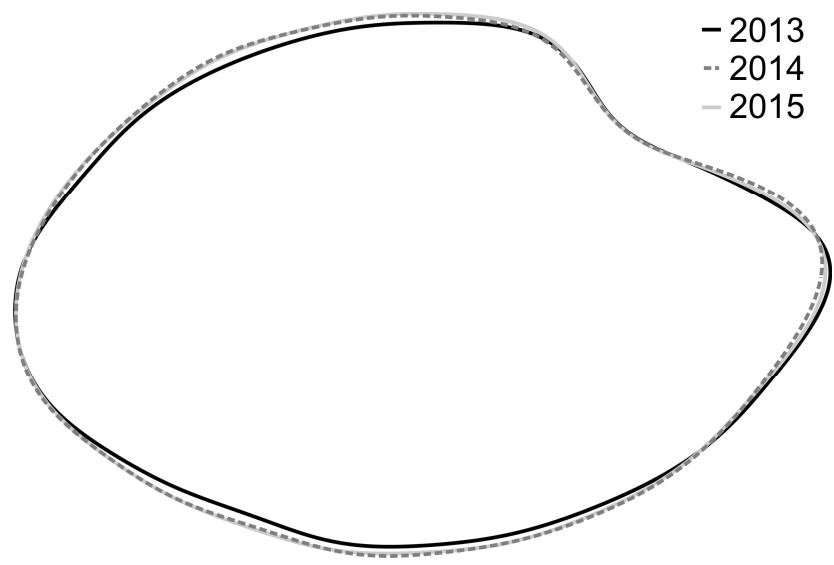

178 Figure 4: Mean otolith shape by sampling year.

179 Reconstruction based on the first 12 harmonics. Number of fishes used for reconstruction: 2013:85; 2014: $100 ; 2015: 170$.

180 A CAP was computed using sampling years as a priori groups in order to test if otolith shapes are specific for each year (Table 2).

Table 2: CAP comparison of Oblada melanura otolith shape Fourier variables using sampling years as a priori groups.

Fourier harmonics 2 to 12 used; fishes included: standard length $>11 \mathrm{~mm}$. m: number of principal component ordination (PCO) axes used for the analysis; N: number of fishes used in the analysis; Variation: proportion of the variation explained by the first $\mathrm{m}$ PCO axes; Groups: number of groups used in the analysis; Threshold: allocation success expected only by chance; Allocation success: proportion of the points from a group truly allocated to this group; $\delta^{2}$ : squared canonical correlation; $p$ : p-value of the permutation test. Cross-validation: Leave-one-out allocation of observations to groups; raw: origin group; column: allocated group.

\begin{tabular}{|c|c|c|c|c|}
\hline CAP & & & & \\
\hline m & & 39 & & \\
\hline \multirow[t]{3}{*}{$\mathbf{N}$} & 2013 & 85 & & \\
\hline & 2014 & 100 & & \\
\hline & 2015 & 170 & & \\
\hline Variation & & $99.91 \%$ & & \\
\hline Groups & & 3 & & \\
\hline Threshold & & $33.33 \%$ & & \\
\hline \multirow[t]{4}{*}{ Allocation success } & Total & $66.48 \%$ & & \\
\hline & 2013 & $69.41 \%$ & & \\
\hline & 2014 & $74.00 \%$ & & \\
\hline & 2015 & $60.59 \%$ & & \\
\hline$\delta^{2}$ & & 0.547 & & \\
\hline$p$ & & 0.0001 & & \\
\hline Cross-validation & 2013 & 2014 & 2015 & Total \\
\hline 2013 & 59 & 7 & 19 & 85 \\
\hline 2014 & 3 & 74 & 23 & 100 \\
\hline 2015 & 25 & 42 & 103 & 170 \\
\hline
\end{tabular}

Inter-annual comparison of otolith shape by means of CAP analysis (Table 2) highlights significant

190 differences between sampling years for otolith shape, with allocation success values higher than threshold and highly significant $\mathrm{p}$ value, confirmed by cross-validation. 
As time pass, juveniles grow and are exposed a longer time to their living conditions which may

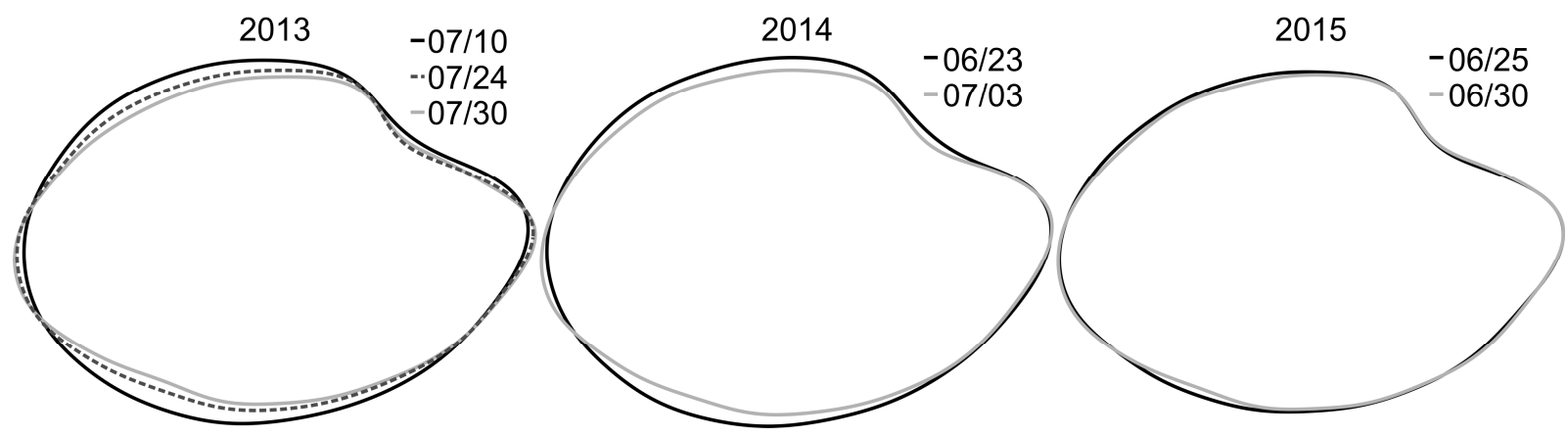

Figure 5: Mean otolith shape by sampling date in 2013, 2014 and 2015.

Reconstruction based on the 12 first harmonics. Number of fishes used for reconstruction: 07/10/2013: 11; 07/24/2013: 39; 07/30/2013: 35; 06/23/2014: 6; 07/03/2014: 94; 06/25/2015: 107; 06/30/2015: 63.

Delays between sampling dates were 14 and 6 days in 2013, 10 days in 2014 and 5 days in 2015. It

seems that the mean otolith shape of each sampling is different each year between dates, even for the

Fourier variables using sampling dates as a priori groups (Table 3). year.

For 2014 and 2015, sites A and B were pooled for each date. S. 1, S. 2, S. 3: samplings 1, 2 and 3. Fourier harmonics 2 to 12 used; fishes included: standard length $>\mathbf{1 1} \mathrm{mm}$. m: number of principal component ordination (PCO) axes used for the analysis; $\mathrm{N}$ : number of fishes used in the analysis; Variation: proportion of the variation explained by the first $\mathrm{m}$ PCO axes; Groups: number of groups used in the analysis; Threshold: allocation success expected, by chance only; Allocation success: proportion of the points from a group truly allocated to this group; $\delta^{2}$ : squared canonical correlation; $p$ : $p$-value of the permutation test. Cross-validation: Leave-one-out allocation of observations to groups; raw: origin group; column: allocated group.

\begin{tabular}{llll}
\hline CAP & $\mathbf{2 0 1 3}$ & $\mathbf{2 0 1 4}$ & $\mathbf{2 0 1 5}$ \\
\hline $\mathrm{m}$ & 15 & 31 & 11
\end{tabular}




\begin{tabular}{|c|c|c|c|c|c|}
\hline \multirow[t]{3}{*}{$\mathbf{N}$} & S. 1 & 11 & 6 & 107 & \\
\hline & S. 2 & 39 & 94 & 63 & \\
\hline & S. 3 & 35 & & & \\
\hline \multicolumn{2}{|l|}{ Variation } & $92.13 \%$ & $99.77 \%$ & $84.79 \%$ & \\
\hline \multicolumn{2}{|l|}{ Groups } & 3 & 2 & 2 & \\
\hline \multicolumn{2}{|l|}{ Threshold } & $33.33 \%$ & $50.00 \%$ & $50.00 \%$ & \\
\hline \multirow[t]{4}{*}{ Allocation success } & Total & $74.12 \%$ & $97.00 \%$ & $82.35 \%$ & \\
\hline & S. 1 & $90.91 \%$ & $83.33 \%$ & $84.11 \%$ & \\
\hline & S. 2 & $74.36 \%$ & $97.87 \%$ & $79.37 \%$ & \\
\hline & S. 3 & $68.57 \%$ & & & \\
\hline \multicolumn{2}{|l|}{$\delta^{2}$} & 0.692 & 0.570 & 0.467 & \\
\hline \multicolumn{2}{|l|}{ p } & 0.0001 & 0.0023 & 0.0001 & \\
\hline \multicolumn{2}{|l|}{ Cross-validation } & S. 1 & S. 2 & S. 3 & Total \\
\hline \multirow[t]{3}{*}{2013} & S. 1 & 10 & 1 & 0 & 11 \\
\hline & S. 2 & 3 & 29 & 7 & 39 \\
\hline & S. 3 & 2 & 9 & 24 & 35 \\
\hline \multirow[t]{2}{*}{2014} & S. 1 & 5 & 1 & & 6 \\
\hline & S. 2 & 2 & 92 & & 94 \\
\hline \multirow[t]{2}{*}{2015} & S. 1 & 90 & 17 & & 107 \\
\hline & S. 2 & 13 & 50 & & 63 \\
\hline
\end{tabular}

216 Allocation success compared to thresholds, $\mathrm{p}$ values, and confirmation by cross-validation reveal

217 significant differences between each sampling date for each year.

$218 \quad 3.2 \quad \underline{\text { Inter-site comparison }}$

219 The main aim of our study is to determine if otolith shape comparison may be a tool to test the effect of

220 environmental conditions on fishes. To achieve this, we compared the two types of sites (A and B) for

221 each sampling date in 2014 and 2015. A representation of the mean otolith shape according to

222 environment type by sampling dates suggests slight differences (Figure 6). 


$\begin{array}{ccc}\text { Date } & \text { Site } & \text { N } \\ 06 / 23 / 2014 & \text { A } & 2 \\ & \text { B } & 4 \\ 07 / 03 / 2014 & \text { A } & 43 \\ & \text { B } & 51 \\ 06 / 25 / 2015 & \text { A } & 60 \\ & \text { B } & 47 \\ 06 / 30 / 2015 & \text { A } & 30 \\ & \text { B } & 33\end{array}$
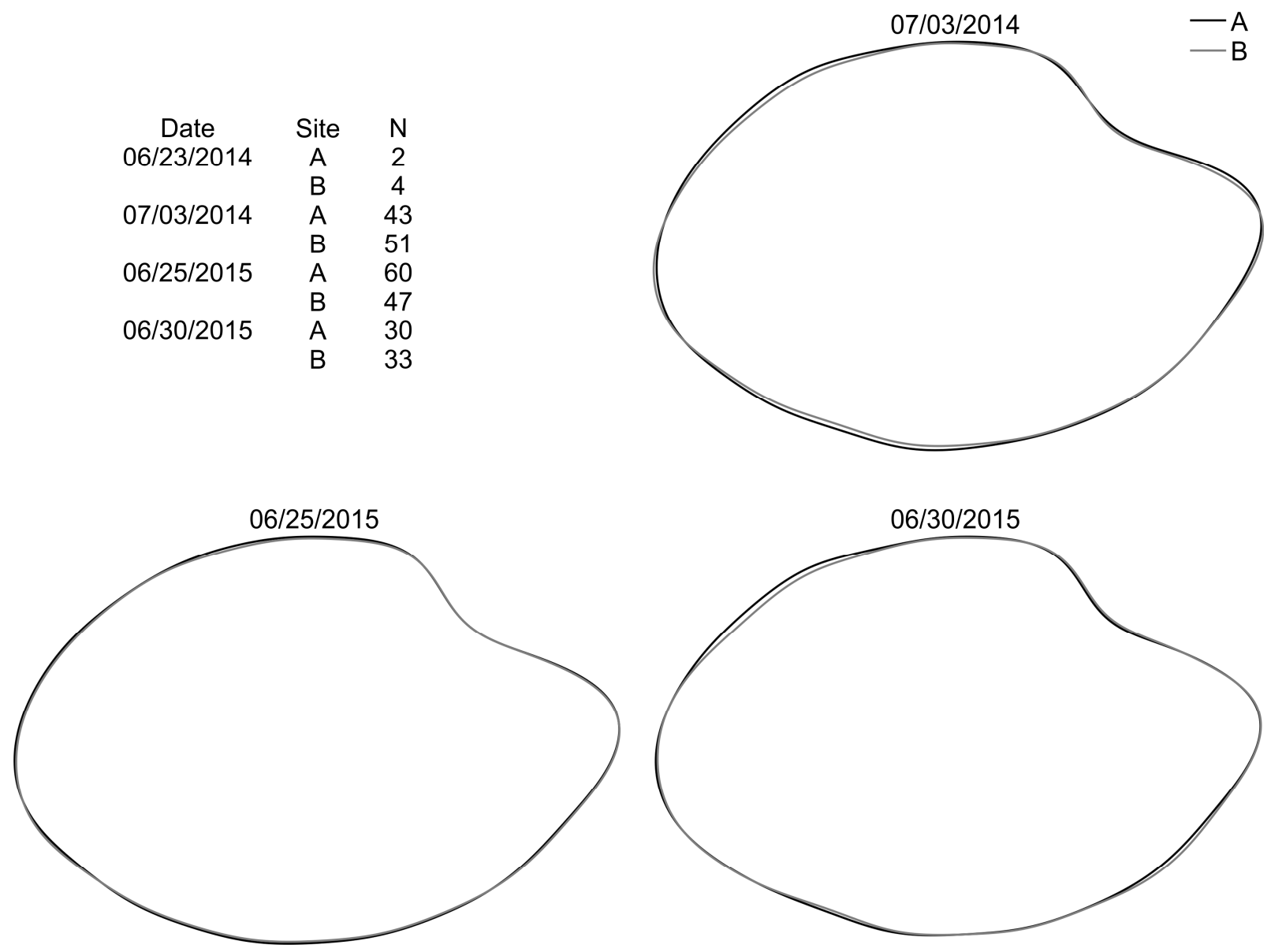

Figure 6: Mean otolith shape by environment type and sampling date.

Reconstruction based on the 12 first harmonics. Number of fishes used for reconstruction: 06/23/2014: $A=2, B=4$; 07/03/2014: A=43, B=51; 06/25/2015: A=60, B=47; 06/30/2015: A=30, B=33. Mean otolith shapes of 06/23/2014 are not represented because of the limited number of fishes.

CAP on otolith shape data with sites as a priori groups is presented in Table 4.

Table 4: CAP comparisons of Oblada melanura otolith shape Fourier variables using types of sites as a priori groups, by sampling date.

Fourier harmonics 2 to 12 used; fishes included: standard length > $11 \mathrm{~mm}$. A: type A; B: type B. m: number of principal component ordination (PCO) axes used for the analysis; N: number of fishes used in the analysis; Variation: proportion of the variation explained by the first $\mathrm{m}$ PCO axes; Groups: number of groups used in the analysis; Threshold: allocation success expected only by chance; Allocation success: proportion of the points from a group truly allocated to this group; $\delta^{2}$ : squared canonical correlation; p: p-value of the permutation test. Cross-validation: Leave-one-out allocation of observations to groups; raw: origin group; column: allocated group.

\begin{tabular}{|c|c|c|c|c|c|}
\hline CAP & & $2014 / 06 / 23$ & $2014 / 07 / 03$ & $2015 / 06 / 25$ & $2015 / 06 / 30$ \\
\hline$M$ & & 2 & 21 & 42 & 11 \\
\hline \multirow[t]{2}{*}{ N } & A & 2 & 43 & 60 & 30 \\
\hline & B & 4 & 51 & 47 & 33 \\
\hline Variation & & $72.50 \%$ & $97.84 \%$ & $>99.99 \%$ & $87.58 \%$ \\
\hline Groups & & 2 & 2 & 2 & 2 \\
\hline Threshold & & $50.00 \%$ & $50.00 \%$ & $50.00 \%$ & $50.00 \%$ \\
\hline
\end{tabular}




\begin{tabular}{|c|c|c|c|c|c|}
\hline \multirow[t]{3}{*}{ Allocation success } & Total & $33.33 \%$ & $63.83 \%$ & $61.68 \%$ & $73.02 \%$ \\
\hline & A & $50.00 \%$ & $65.12 \%$ & $63.33 \%$ & $83.33 \%$ \\
\hline & B & $25.00 \%$ & $62.75 \%$ & $59.57 \%$ & $63.64 \%$ \\
\hline$\delta^{2}$ & & 0.232 & 0.368 & 0.474 & 0.416 \\
\hline$p$ & & 0.7316 & 0.0150 & 0.1125 & 0.0004 \\
\hline Cross-validation & & A & B & Total & \\
\hline \multirow[t]{2}{*}{$2014 / 06 / 23$} & A & 1 & 1 & 2 & \\
\hline & B & 3 & 1 & 4 & \\
\hline \multirow[t]{2}{*}{ 2014/07/03 } & A & 28 & 15 & 43 & \\
\hline & B & 19 & 32 & 51 & \\
\hline \multirow[t]{2}{*}{$2015 / 06 / 25$} & A & 38 & 22 & 60 & \\
\hline & B & 19 & 28 & 47 & \\
\hline \multirow[t]{2}{*}{$2015 / 06 / 30$} & A & 25 & 5 & 30 & \\
\hline & B & 12 & 21 & 33 & \\
\hline
\end{tabular}

237 CAP highlights a change of results with time, for each year, from no significant difference between sites

238 for the first sampling to significant difference between sites for the second sampling.

\section{Discussion}

240 Anthropic impacts on coastal ecosystems on the French Riviera include urbanisation of the littoral zone,

241 sewage discharge and yachting (Petrosillo et al., 2009). Because of this pressure upon coastal

242 ecosystems, pollution monitoring is a necessity for both human and environmental health. Thus, we

243 have investigated whether the otolith shape of Oblada melanura juveniles could be used as

244 environmental indicator. In order to answer this question, we tested different parameters that might

245 influence otolith shape analysis.

246 According to otolith growth characteristics, several parameters, such as fish size or growing (Campana 247 and Casselman, 1993), may prevent the use of juvenile-fish otoliths as environmental indicator. Thus, we

248 first focused on the impact of fish size on otolith shape. Otolith shape is known to change with fish 249 growth and age (Javor et al., 2011), therefore most of the data dealing with otolith shape variation 250 comes from adult fishes (Bacha et al., 2016, 2014; Begg et al., 2001; Bose et al., 2018; Campana and 251 Casselman, 1993; Gaemers, 1983; Galley et al., 2006; García-Gómez et al., 2002; Morrow, 1979;

252 Rodgveller et al., 2017; Smith et al., 2002; Tracey et al., 2006). This shape transformation is particularly 
strong during the first months of fish life, with a progression from a round larval nucleus to the definitive adult-shaped otolith. We observed that the otolith shape of Oblada melanura juveniles varies with fish length (Figure 1), from a "rounded" smooth shape to a "ovoid" jagged adult shape, and that fishes from a same sampling differ in standard length (Figure 2), highlighting the necessity to determine a size limit to have otolith shape stabilisation. We have demonstrated that, when comparing 0 . melanura right sagitta shapes by standard length groups, differences between groups tend to disappear for fishes larger than a standard length of $11 \mathrm{~mm}$. The limited difference between size groups indicates that otolith shape stabilises above $11 \mathrm{~mm}$ for 0 . melanura. So, working on fish with a standard length of $\geq 11$ $\mathrm{mm}$ is necessary in order to limit fish-size influence when comparing different samples.

We tested independently other parameters that differed between our samplings, i.e. years and dates. We made an inter-annual comparison of otolith shape (Table 2), which highlights significant differences between sampling years, as observed in adult fishes (Begg and Brown, 2000; Castonguay et al., 1991), even if this effect was not systematically shown (Galley et al., 2006). This may indicate that environmental conditions are not strictly the same each year at the same site. In fact, according to meteorological records, lower temperatures, increased precipitation and higher wind intensity were observed in 2013 compared to 2014 and 2015. These meteorological conditions are associated to a later spawning and consequently a later settlement. Consequently, samples from different years must be analysed independently. In addition, it appears that otolith shape changes according to sampling date

271 within a specific year. Therefore, it is important to consider the time between samplings. From the 272 present results, a time delay of 5 days or more between two samples appears to influence otolith shape 273 and care must then be taken to only compare samples with less than five days interval (Figure 5). As we 274 were working on fishes with a standard length of $\geq 11 \mathrm{~mm}$, the impact of fish length on otolith shape 275 was limited. In fact, this difference may be mainly due to environmental influences as described for 276 adults (Bose et al., 2018; Campana and Casselman, 1993; Galley et al., 2006; Rodgveller et al., 2017; 

Secor and Dean, 1989; Smith et al., 2002). The longer a fish stays in an environment, the more this fish will be influenced by the local environmental conditions. In each of the two selected sites with different environmental conditions, i.e. low-level pollution versus recreational harbour, we compared otolith shape with regard to increasing fish's stay duration, i.e. length of time that fish stay at the site. Figure 6 and Table 4 show no difference between sites for the first sampling but demonstrate significant otolith shape differences between sites for the second sampling. Note that in the first sampling of 2014, only six fishes were considered (because of the $11 \mathrm{~mm}$ size limit), which has limited the significance of the result. A possible explanation of the absence of difference in the first samplings and the presence of difference in the second ones is that for the first samplings the fish's stay duration was not sufficient for the fish to undergo sufficient environmental exposure to impact otolith shape, in contrast to the second samplings. Indeed, it has been shown that, in the case of stock comparisons, a few-weeks environmental event, such as starvation, does not impact otolith shape (Campana, 1983; Campana and Casselman, 1993; Marshall and Parker, 1982; Neilson and

290 Geen, 1985). Finally, when working with fishes from the same year, the same sampling date, and of 291 standard length greater than the size limit, juvenile otolith shape comparison proved to be effective in 292 discriminating between two samples from different sites corresponding to different types of 293 environment.

\section{Conclusion}

295 To conclude, on the basis of these data, we have demonstrated that juvenile 0 . melanura otolith 296 (sagitta) shape comparison is an effective method to discriminate between groups of individuals exposed to different conditions, such as "preserved from" versus "exposed to" the impact of a recreational harbour. A condition of use for this method is to determine the fish size limit and to ensure that fish analyses are conducted on individuals with a length greater than this size limit (for $O$. melanura: 
above $11 \mathrm{~mm}$ fish standard length). It is also necessary to work on juveniles sampled on the same date or on dates separated by less than 5 days. A direct application of this method is the comparison of a larger number of environmental conditions, replicated in different geographical zones. Another use is to test the effect of different disturbance intensities. This method, validated on 0 . melanura, may also be applicable to other species with sedentary juveniles, and is a promising tool for environmental management.

\section{$6 \quad$ Acknowledgements}

Authors wish to thank $\operatorname{Dr}$ P. Thiriez and $\operatorname{Dr}$ A. Calò for their help in designing the sampling method; Mr V.

Principale, Mr C. Malien, Dr V. Dani and Mr R. Zamoum for their help during sampling sessions; Dr A. Di

sampling sessions and for his advice.

\section{$7 \quad$ Funding}

312 This work is part of a Ph.D. thesis supported by the French Ministère de l'Enseignement Supérieur et de la Recherche and by the Fondation UNICE.

\section{Bibliography}

Anderson, M.J., 2001. Permutation tests for univariate or multivariate analysis of variance and regression. Can. J. Fish. Aquat. Sci. 58, 626-639. https://doi.org/10.1139/f01-004

Anderson, M.J., Gorley, R.N., Clarke, K.R., 2008. PERMANOVA+ for PRIMER: Guide to Software and Statistical Methods. PRIMER-E Ltd, Plymouth, UK.

Anderson, M.J., Willis, T.J., 2003. Canonical Analysis of Principal Coordinates: A Useful Method of Constrained Ordination for Ecology. Ecology 84, 511-525. https://doi.org/10.1890/00129658(2003)084[0511:CAOPCA]2.0.CO;2

Anken, R.H., Werner, K., Ibsch, M., Rahmann, H., 1998. Fish inner ear otolith size and bilateral asymmetry during development. Hear. Res. 121, 77-83.

Bacha, M., Jemaa, S., Hamitouche, A., Rabhi, K., Amara, R., 2014. Population structure of the European anchovy, Engraulis encrasicolus, in the SW Mediterranean Sea, and the Atlantic Ocean: evidence from otolith shape analysis. ICES J. Mar. Sci. J. Cons. 2429-2435. https://doi.org/10.1093/icesjms/fsu097 
Bacha, M., Jeyid, A.M., Jaafour, S., Yahyaoui, A., Diop, M., Amara, R., 2016. Insights on stock structure of round sardinella Sardinella aurita off north-west Africa based on otolith shape analysis. J. Fish Biol. 89, 2153-2166. https://doi.org/10.1111/jfb.13117

Begg, G.A., Brown, R.W., 2000. Stock Identification of Haddock Melanogrammus aeglefinus on Georges Bank Based on Otolith Shape Analysis. Trans. Am. Fish. Soc. 129, 935-945. https://doi.org/10.1577/1548-8659(2000)129<0935:SIOHMA>2.3.CO;2

Begg, G.A., Overholtz, W.J., Munroe, N.J., 2001. The use of internal otolith morphometrics for identification of haddock (Melanogrammus aeglefinus) stocks on Georges Bank. Fish. Bull. 99, 11.

Bonhomme, V., Picq, S., Gaucherel, C., Claude, J., 2014. Momocs: Outline Analysis Using R. J. Stat. Softw. 56, 1-24. https://doi.org/10.18637/jss.v056.i13

Bose, A.P.H., McCallum, E.S., Raymond, K., Marentette, J.R., Balshine, S., 2018. Growth and otolith morphology vary with alternative reproductive tactics and contaminant exposure in the round goby Neogobius melanostomus. J. Fish Biol. 93, 674-684. https://doi.org/10.1111/jfb.13756

Campana, S.E., 1983. Feeding periodicity and the production of daily growth increments in otoliths of steelhead trout (Salmo gairdneri) and starry flounder (Platichthys stellatus). Can. J. Zool. 61, 1591-1597. https://doi.org/10.1139/z83-214

Campana, S.E., Casselman, J.M., 1993. Stock Discrimination Using Otolith Shape Analysis. Can. J. Fish. Aquat. Sci. 50, 1062-1083. https://doi.org/10.1139/f93-123

Castonguay, M., Simard, P., Gagnon, P., 1991. Usefulness of Fourier Analysis of Otolith Shape for Atlantic Mackerel (Scomber scombrus) Stock Discrimination. Can. J. Fish. Aquat. Sci. 48, $296-302$. https://doi.org/10.1139/f91-041

Cheminée, A., Sala, E., Pastor, J., Bodilis, P., Thiriet, P., Mangialajo, L., Cottalorda, J.-M., Francour, P., 2013. Nursery value of Cystoseira forests for Mediterranean rocky reef fishes. J. Exp. Mar. Biol. Ecol. 442, 70-79. https://doi.org/10.1016/j.jembe.2013.02.003

Cresson, P., Bouchoucha, M., Miralles, F., Elleboode, R., Mahé, K., Marusczak, N., Thebault, H., Cossa, D., 2015. Are red mullet efficient as bio-indicators of mercury contamination? A case study from the French Mediterranean. Mar. Pollut. Bull. 91, 191-199. https://doi.org/10.1016/j.marpolbul.2014.12.005

Cuadros, A., Moranta, J., Cardona, L., Thiriet, P., Pastor, J., Arroyo, N.L., Cheminée, A., 2017. Seascape attributes, at different spatial scales, determine settlement and post-settlement of juvenile fish. Estuar. Coast. Shelf Sci. 185, 120-129. https://doi.org/10.1016/j.ecss.2016.12.014

Damiens, G., Gnassia-Barelli, M., Loquès, F., Roméo, M., Salbert, V., 2007. Integrated biomarker response index as a useful tool for environmental assessment evaluated using transplanted mussels. Chemosphere 66, 574-583. https://doi.org/10.1016/j.chemosphere.2006.05.032

Degens, E.T., Deuser, W.G., Haedrich, R.L., 1969. Molecular structure and composition of fish otoliths. Mar. Biol. 2, 105-113. https://doi.org/10.1007/BF00347005

Ducrotoy, J.-P., Yanagi, T., 2008. Tools and concepts on ecological quality of coastal and estuarine environments. Mar. Pollut. Bull., EMECS 7/ECSA 40, Caen (France), May 2006 57, 1-2. https://doi.org/10.1016/j.marpolbul.2008.04.029

Freeman, H., 1974. Computer Processing of Line-Drawing Images. ACM Comput. Surv. 6, 57-97. https://doi.org/10.1145/356625.356627

Gaemers, P.A.M., 1983. Taxonomic Position of the Cichlidae (Pisces, Perciformes) as Demonstrated By the Morphology of Their Otoliths. Neth. J. Zool. 34, 566-595. https://doi.org/10.1163/002829684X00290

Galley, E.A., Wright, P.J., Gibb, F.M., 2006. Combined methods of otolith shape analysis improve identification of spawning areas of Atlantic cod. ICES J. Mar. Sci. J. Cons. 63, 1710-1717. https://doi.org/10.1016/j.icesjms.2006.06.014 
García-Gómez, A., de la Gándara, F., Raja, T., 2002. Utilización del aceite de clavo, Syzygium aromaticum L. (Merr. \& Perry), como anestésico eficaz y económico para labores rutinarias de manipulación de peces marinos cultivados. Bol. Inst. Esp. Oceanogr. 18, 21-23.

Giardina, C.R., Kuhl, F.P., 1977. Accuracy of curve approximation by harmonically related vectors with elliptical loci. Comput. Graph. Image Process. 6, 277-285. https://doi.org/10.1016/S0146$664 \times(77) 80029-4$

Gonzalez-Salas, C., Lenfant, P., 2007. Interannual variability and intraannual stability of the otolith shape in European anchovy Engraulis encrasicolus (L.) in the Bay of Biscay. J. Fish Biol. 70, 35-49. https://doi.org/10.1111/j.1095-8649.2006.01243.x

Hildering, A., Keessen, A.M., Rijswick, H.F.M.W. van, 2009. Tackling pollution of the Mediterranean Sea from land-based sources by an integrated ecosystem approach and the use of the combined international and European legal regimes. Utrecht Law Rev. 5. https://doi.org/10.18352/ulr.96

Iwata, H., Ukai, Y., 2002. SHAPE: A Computer Program Package for Quantitative Evaluation of Biological Shapes Based on Elliptic Fourier Descriptors. J. Hered. 93, 384-385. https://doi.org/10.1093/jhered/93.5.384

Javor, B., Lo, N., Vetter, R., 2011. Otolith morphometrics and population structure of Pacific Sardine (Sardinops sagax) along the west coast of North America. Fish. Bull. Natl. Ocean. Atmospheric Adm. 109, 402-415.

Jemaa, S., Bacha, M., Khalaf, G., Dessailly, D., Rabhi, K., Amara, R., 2015. What can otolith shape analysis tell us about population structure of the European sardine, Sardina pilchardus, from Atlantic and Mediterranean waters? Neth. J. Sea Res. 96, 11-17. https://doi.org/10.1016/j.seares.2014.11.002

Konstantinou, I.K., Albanis, T.A., 2004. Worldwide occurrence and effects of antifouling paint booster biocides in the aquatic environment: a review. Environ. Int. 30, 235-248. https://doi.org/10.1016/S0160-4120(03)00176-4

Kuhl, F.P., Giardina, C.R., 1982. Elliptic Fourier features of a closed contour. Comput. Graph. Image Process. 18, 236-258. https://doi.org/10.1016/0146-664X(82)90034-X

L'Abée-Lund, J.H., 1988. Otolith shape discriminates between juvenile Atlantic salmon, Salmo salar L., and brown trout, Salmo trutta L. J. Fish Biol. 33, 899-903. https://doi.org/10.1111/j.10958649.1988.tb05538.x

Marshall, S.L., Parker, S.S., 1982. Pattern Identification in the Microstructure of Sockeye Salmon (Oncorhynchus nerka) Otoliths. Can. J. Fish. Aquat. Sci. 39, 542-547. https://doi.org/10.1139/f82-077

McCoy, E.J.A., Johnson, L.T., 2010. Boating Pollution Economics \& Impacts.

Mestres, M., Sierra, J.P., Mösso, C., Sánchez-Arcilla, A., 2010. Sources of contamination and modelled pollutant trajectories in a Mediterranean harbour (Tarragona, Spain). Mar. Pollut. Bull. 60, 898907. https://doi.org/10.1016/j.marpolbul.2010.01.002

Morales-Nin, B., 2000. Review of the growth regulation processes of otolith daily increment formation. Fish. Res. 46, 53-67. https://doi.org/10.1016/S0165-7836(00)00133-8

Morrow, J.E., 1979. Preliminary keys to otoliths of some adult fishes of the Gulf of Alaska, Bering Sea and Beaufort Sea (No. 420), NOAA Technical Report NMFS Circular. U.S. Department of Commerce, NOAA, NMFS, Washington, DC.

Neiffer, D.L., Stamper, M.A., 2009. Fish sedation, analgesia, anesthesia, and euthanasia: considerations, methods, and types of drugs. ILAR J. 50, 343-360.

Neilson, J.D., Geen, G.H., 1985. Effects of feeding regimes and diel temperature cycles on otolith increment formation in juvenile chinook salmon, Oncorhynchus tshawytscha. Fish. Bull. 83, 91:101.

Panella, G., 1971. Fish otoliths: daily growth layers and periodical patterns. Science 173, 1124-1127. 
Petrosillo, I., Valente, D., Zaccarelli, N., Zurlini, G., 2009. Managing tourist harbors: Are managers aware of the real environmental risks? Mar. Pollut. Bull. 58, 1454-1461. https://doi.org/10.1016/j.marpolbul.2009.06.013

Rodgveller, C.J., Hutchinson, C.E., Harris, J.P., Vulstek, S.C., lii, C.M.G., 2017. Otolith shape variability and associated body growth differences in giant grenadier, Albatrossia pectoralis. PLOS ONE 12, e0180020. https://doi.org/10.1371/journal.pone.0180020

Ross, L.G., Ross, B., 2008. Anaesthetic and Sedative Techniques for Aquatic Animals, 3rd Edition. Blackwell Publishing, Oxford.

Secor, D.H., Dean, J.M., 1989. Somatic Growth Effects on the Otolith-Fish Size Relationship in Young Pond-reared Striped Bass, Morone saxatilis. Can. J. Fish. Aquat. Sci. 46, 113-121. https://doi.org/10.1139/f89-015

Secor, D.H., Dean, J.M., Leban, E.H., 1992. Otolith removal and preparation for microstructural examination, in: Stevenson, D.K., Campana, S.E. (Eds.), Otolith Microstructure Examination and Analysis, Canadian Special Publication of Fisheries and Aquatic Sciences. Department of Fisheries and Ocean, Ottawa, pp. 19-57.

Secor, D.H., Henderson-Arzapalo, A., Piccoli, P.M., 1995. Can otolith microchemistry chart patterns of migration and habitat utilization in anadromous fishes? J. Exp. Mar. Biol. Ecol. 192, 15-33. https://doi.org/10.1016/0022-0981(95)00054-U

Smith, P.J., Robertson, S.G., Horn, P.L., Bull, B., Anderson, O.F., Stanton, B.R., Oke, C.S., 2002. Multiple techniques for determining stock relationships between orange roughy, Hoplostethus atlanticus, fisheries in the eastern Tasman Sea. Fish. Res. 58, 119-140. https://doi.org/10.1016/S01657836(01)00389-7

Stransky, C., Murta, A.G., Schlickeisen, J., Zimmermann, C., 2008. Otolith shape analysis as a tool for stock separation of horse mackerel (Trachurus trachurus) in the Northeast Atlantic and Mediterranean. Fish. Res., Horse Mackerel: Identification of Stocks 89, 159-166. https://doi.org/10.1016/j.fishres.2007.09.017

Telli Karakoc, F., Hewer, A., Phillips, D.H., Gaines, A.F., Yuregir, G., 1997. Biomarkers of marine pollution observed in species of mullet living in two eastern Mediterranean harbours. Biomarkers 2, 303309. https://doi.org/10.1080/135475097231535

Thia-eng, C., Ross, A.S., 1998. Marine Pollution Prevention and Management in the East Asian Seas: A Paradigm Shift in Concept, Approach and Methodology, MPP-EAS Technical Report. Global Environment Facility/United Nations Development Programme/International Maritime Organization Regional Programme for the Prevention and Management of Marine Pollution in the East Asian Seas, Quezon City, Philippines.

Thiriet, P.D., Franco, A.D., Cheminée, A., Guidetti, P., Bianchimani, O., Basthard-Bogain, S., Cottalorda, J.M., Arceo, H., Moranta, J., Lejeune, P., Francour, P., Mangialajo, L., 2016. Abundance and Diversity of Crypto- and Necto-Benthic Coastal Fish Are Higher in Marine Forests than in Structurally Less Complex Macroalgal Assemblages. PLOS ONE 11, e0164121. https://doi.org/10.1371/journal.pone.0164121

Tracey, S.R., Lyle, J.M., Duhamel, G., 2006. Application of elliptical Fourier analysis of otolith form as a tool for stock identification. Fish. Res. 138-147. https://doi.org/10.1016/j.fishres.2005.10.013

VanderKooy, S., Guindon-Tisdel, K., 2003. A Practical Handbook for Determining the Age of Gulf of Mexico Fishes, Interjurisdictional Fisheries. Gulf States Marine Fisheries Commission, Ocean Springs. 


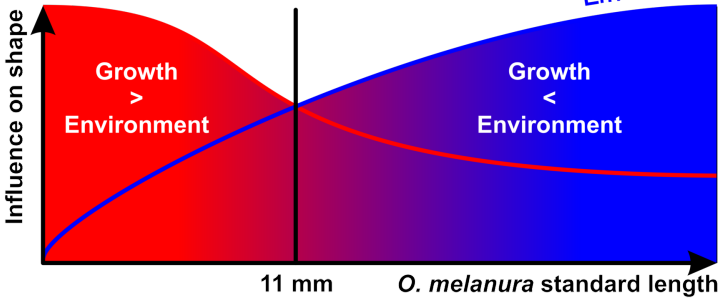

